\title{
KESADARAN GENDER YANG ISLAMI
}

\author{
Nurdeni Dahri ${ }^{1}$ \\ Penghulu di Kemenag Kota Pekanbaru
}

\begin{abstract}
Biological differences between men and women have in the implementation of social and cultural life. There has been a gender gap due to the multiplicity of interpretations of the notion of gender itself. In-depth research is needed to determine the cause of the gap, let alone Islam declared the doctrine that leads to gender bias. Based on the discussion in this paper is declared Gender division of roles and responsibilities between women and men as a result of socio-cultural construction of society, which can be changed according to the demands of the changing times. While sex (gender: male and female) are not changed and the nature of God. In the teachings of Islam there is no difference between women and men in all its aspects, distinguishing only charity and piety.
\end{abstract}

Keyword: gender, bias and Islam

Abstrak: Perbedaan secara biologis antara laki-laki dan perempuan telah mempunyai impelementasi di dalam kehidupan sosial budaya. Telah terjadi kesenjangan gender dikarenakan bermacam-macamnya penafsiran tentang pengertian gender itu sendiri. Perlu penelitian yang mendalam penyebab terjadinya kesenjangan tersebut, apalagi Islam dinyatakan sebagai ajaran yang menyebabkan terjadinya bias gender. Berdasarkan pembahasan dalam tulisan ini dinyatakan Gender adalah pembedaan peran dan tanggung jawab antara perempuan dan lakilaki sebagai hasil konstruksi sosial budaya masyarakat, yang dapat berubah sesuai dengan tuntutan perubahan zaman. Sedangkan seks (jenis kelamin: laki-laki dan perempuan) tidak berubah dan merupakan kodrat Tuhan. Dalam ajaran agama Islam tidak ada perbedaan antara perempuan dan laki-laki dalam segala aspeknya, pembedanya hanya amal dan taqwa.

Kata Kunci: gender, bias dan Islam

\section{PENDAHULUAN}

Masalah kesadaran gender dalam beberapa dasawarsa belakangan ini, termasuk di Indonesia telah mencuat ke permukaan. Berbagai struktur dan kultur yang selama ini mengabaikan perempuan digugat; dan upaya dekonstruksi terhadap pemahaman dan pelaksanaannya dilakukan.

Salah satu faktor yang mempengaruhi terjadinya kesenjangan gender adalah dikarenakan bermacammacamnya penafsiran tentang pengertian gender itu sendiri. Seringkali gender dipersamakan dengan sex (jenis kelamin laki-laki dan perempuan), dan pembagian jenis kelamin laki-laki dan perempuan ini serta peran dan tanggung-jawabnya masing-masing, telah dibuat sedemikian rupa dan berlalu dari tahun ke tahun bahkan dari abad ke abad, sehingga lama kelamaan 
masyarakat tidak lagi mengenali mana yang gender dan mana yang sex. Bahkan peran gender oleh masyarakat kemudian diyakini seolah-olah merupakan kodrat yang diberikan Tuhan.

Sebagai akibat dari pembagian peran dan kedudukan yang sudah melembaga antara laki-laki dan perempuan, baik secara langsung berupa perlakuan/sikap, maupun tidak langsung berupa dampak suatu peraturan perundang-undangan dan kebijakan, telah menimbulkan berbagai ketidak-adilan. Ketidak-adilan ini telah mengakar dalam sejarah, adat-istiadat, norma hukum ataupun struktur dalam masyarakat.

Ketidak-adilan ini boleh jadi timbul dikarenakan adanya keyakinan dan pembenaran yang ditanamkan sepanjang peradaban manusia dalam berbagai bentuknya, yang tidak hanya menimpa kepada kaum perempuan, akan tetapi juga menimpa kaum lakilaki, walau secara menyeluruh ketidakadilan gender dalam berbagai kehidupan ini lebih banyak menimpa kaum perempuan.

Perbedaan secara biologis antara laki-laki dan perempuan telah mempunyai impelementasi di dalam kehidupan sosial budaya. Persepsi yang seolah-olah mengendap di dalam bawah sadar seseorang ialah jika seseorang mempunyai atribut biologis, seperti penis pada diri laki-laki atau vagina pada diri perempuan, maka itu juga menjadi atribut gender yang bersangkutan dan selanjutnya akan menentukan peran sosialnya di dalam masyarakat.

\section{PEMBAHASAN \\ Pengertian Gender}

Kata "gender" berasal dari bahasa Inggeris "gender", dalam Kamus Bahasa Inggeris-Indonesia, berarti "jenis kelamin". ${ }^{2}$ Sedangkan dalam Webster's New World Dictionary, gender diartikan sebagai " perbedaan yang tampak antara laki-laki dan perempuan dilihat dari segi nilai dan tingkah laku". ${ }^{3}$

Melalui pengertian dari kamus di atas, sebenarnya kurang tepat, karena seolah-olah gender disamakan pengertiannya dengan sex (yang berarti jenis kelamin). Kalau dilihat dalam Kamus Besar Bahasa Indonesia, kata gender memang belum masuk dalam perbendaharaannya, akan tetapi istilah gender ini lebih populer di lingkungan Kantor Kementerian Pemberdayaan Perempuan. Dengan demikian untuk memudahkan pemahaman kita terhadap kata gender tersebut, ada baiknya merujuk pada penjelasan pemerintah melalui Kantor Kementerian Pemberdayaan Perempuan sebagaimana juga yang tertuang dalam Instruksi Presiden RI No. 9 tahun 2000, sebagai berikut:

Gender adalah suatu konsep kultural yang berupaya membuat 
perbedaan dalam hal peran, perilaku, mentalitas, karateristik emosional antara laki-laki dan perempuan yang berkembang dalam masyarakat. ${ }^{4}$ Artinya gender merupakan sebuah konstruksi sosio-kultural, sebuah kesepakatan masyarakat yang memberikan batasan kepada laki-laki dan perempuan secara mencolok. Dinyatakan oleh Caplan perbedaan lakilaki dan perempuan tidaklah sekedar biologis, namun melalui proses sosial dan kultural. Oleh karena itu gender bukanlah jenis kelamin perempuan atau jenis kelamin laki-laki dari segi biologisnya (sex). ${ }^{5}$ Tapi gender akan selalu berubah dari waktu ke waktu, dari tempat ke tempat bahkan dari kelas ke kelas, sementara jenis kelamin biologis (sex) akan tetap tidak berubah.

Gender bukanlah kodrat dan ketentuan Tuhan. Oleh karena itu gender berkaitan dengan bagaimana seharusnya laki-laki dan perempuan berperan dan bertindak sesuai dengan tata nilai yang terstruktur oleh ketentuan sosial dan budaya di tempat mereka berada. Dengan kata lain, gender adalah perbedaan peran dan tanggung-jawab antar perempuan dan laki-laki sebagai hasil konstruksi sosial budaya masyarakat.

Dari uraian diatas dapat disimpulkan, bahwa gender adalah :

1. Konstruksi/bentuk social

2. Tidak dimiliki sejak lahir

3. Bisa dibentuk/bisa berubah

4. Dipengaruhi oleh, a) Tempat, b) Waktu/zaman, c) Suku/ras/bangsa, d) Budaya, e) Status sosial, f) Pemahaman agama, g) Ideologi Negara, h) Politik, hukum dan ekonomi.

5. Karenanya gender, a) Bukan kodrat, b) Dibuat manusia, c) Bisa dipertukarkan, d) Relatif, e) Berbeda dengan ciri-ciri yang terdapat pada laki-laki maupun perempuan (jenis kelamin, biologis, natur).

Pengertian sex adalah pembagian jenis kelamin yang terdiri dari perempuan dan laki-laki, yang telah ditentukan oleh Tuhan, sebagai kodrat Allah SWT., Perbedaan biologis antara perempuan dan laki-laki dapat dilihat baik dari ciri fisik primer maupun ciri fisik sekunder dari organ dan fungsi reproduksinya. Karenanya seks relatif tidak dapat ditukar atau diubah.

Ciri-ciri laki-laki dan perempuan dapat dillihat dalam matrik berikut ini: 


\begin{tabular}{|c|c|c|}
\hline & LAKI LAKI & PEREMPUAN \\
\hline Primer & $\begin{array}{ll}\text { - } & \text { Penis } \\
\text { - } & \text { Kantung zakar (Scotrum) } \\
\text { - } & \text { Buah zakar (testis) } \\
\text { - } & \text { Sperma/mani } \\
\text { - } & \text { Prostat (kelenjar) pengaturan } \\
& \text { pengeluaran sperma dan air } \\
& \text { seni / kelenjar kemih } \\
\end{array}$ & $\begin{array}{ll}- & \text { Vagina (liang senggama) } \\
- & \text { Ovarium (indung telur) } \\
- & \text { Ovum (sel telur) } \\
- & \text { Uterus } \\
- & \text { Menyusui } \\
- & \text { Haid } \\
- & \text { Rahim } \\
\end{array}$ \\
\hline Sekunder & $\begin{array}{ll}- & \text { Bulu dada / tangan } \\
\text { - } & \text { Jakun } \\
\text { - } & \text { Suara berat } \\
\text { - } & \text { Berkumis }\end{array}$ & $\begin{array}{ll}\text { - } & \text { Kulit halus } \\
\text { - } & \text { Suara lebih bernada tinggi } \\
\text { - } & \text { Dada besar }\end{array}$ \\
\hline
\end{tabular}

Ketentuan ini berlaku sejak dahulu kala, sekarang, dan akan berlaku selamanya. Uraian di atas memberikan kesimpulan kepada kita bahwa, Jenis Kelamin Biologis (seks) adalah:

1. Bawaan

2. Kodrat

3. Buatan Tuhan

4. Mutlak
Dan tidak dipengaruhi oleh:

1. Tempat

2. Waktu/zaman

3. Ras/suku/bangsa

4. Budaya

5. Negara ideologi

Karenanya: tidak bisa berubah, tetap dan hanya dimiliki laki-laki saja atau perempuan saja (nature). Untuk memperjelas perbedaan antara gender dan sex dapat dilihat pada skema berikut ini;

\begin{tabular}{|l|l|}
\hline \multicolumn{1}{|c|}{ GENDER } & \multicolumn{1}{c|}{ SEX (Jenis Kelamin) } \\
\hline Dapat berubah & Tidak dapat berubah \\
Dapat dipertukarkan & Tidak dapat dipertukarkan \\
Tergantung waktu & Berlaku sepanjang masa \\
Tergantung budaya setempat & Berlaku di mana saja \\
Bukan merupakan Kodrat Tuhan & Merupakan Kodrat Tuhan \\
Buatan manusia & Ciptaan Tuhan \\
\hline
\end{tabular}

Pemahaman atas konsep gender sesungguhnya merupakan isu mendasar dalam rangka menjelaskan masalah hubungan antara kaum perempuan dan kaum laki-laki, atau masalah hubungan kemanusiaan kita.

\section{Gender dalam Perspektif Islam}

Sebelum menguraikan bagaimana pandangan Islam terhadap gender, perlu dikemukakan terlebih dahulu pandangan masyarakat dunia secara umum terhadap perempuan, terutama sebelum turunnya kitab suci Alquran. 
Kemudian baru ditelaah bagaimana pandangan Alquran terhadap gender, serta bagaimana penafsiran ulama terdahulu dan kontemporer terhadap ayat-ayat Alquran tersebut.

Sejarah telah menginformasikan bahwa sebelum diturunkannya kitab suci Alquran, berbagai peradaban umat manusia telah berkembang sedemikian rupa, seperti halnya peradaban bangsa Yunani, Romawi, India, Cina dan yang lainnya. Dan juga sebelum datangnya agama Islam, telah datang terlebih dahulu berbagai agama, seperti agama Zoroaster, Buddha, dan yang paling belakangan adalah agama Yahudi dan Nasrani.

Pada puncak peradaban Yunani, perempuan tidak mendapat penghargaan yang adil, karena mereka dianggap alat pemenuhan naluri seks laki-laki. Kaum laki-laki diberi kebebasan sedemikian rupa untuk memenuhi kebutuhan dan selera tersebut, dan para perempuan dipuja untuk itu. Patung-patung telanjang yang terlihat dewasa ini di Eropa adalah merupakan bukti yang menyatakan pandangan itu.

Peradaban Romawi juga tidak begitu berbeda dengan Yunani, menjadikan perempuan sepenuhnya berada di bawah kekuasaan ayahnya. Setelah kawin, kekuasaan pindah ke tangan suami. Kekuasaan ini mencakup kewenangan menjual, mengusir, menganiaya dan membunuh. Peristiwa tragis ini berlangsung sampai pada abad
V Masehi. Segala hasil usaha perempuan, menjadi hak milik keluarganya yang laki-laki.

Pada zaman Kaisar Konstantin (abad XV), terjadi sedikit perubahan dengan diundangkannya hak pemilikan terbatas bagi perempuan, dengan catatan bahwa setiap transaksi harus disetujui terlebih dahulu oleh keluarga (suami/ayah).

Peradaban Hindu dan Cina, juga tidak lebih baik. Hak hidup bagi seorang perempuan yang telah bersuami harus berakhir pada saat kematian suaminya, istri terkadang harus dibakar hiduphidup pada saat mayat suaminya dibakar. Tradisi ini baru berakhir pada abad XVII Masehi.

Sepanjang abad pertengahan nasib perempuan tetap sangat memperihatinkan, sampai dengan tahun 1805 perundang-undangan Inggeris masih mengakui hak suami untuk menjual istrinya, bahkan sampai dengan tahun 1882 perempuan Inggeris belum lagi mempunyai hak kepemilikan harta benda secara penuh, termasuk hak menuntut ke pengadilan. Untuk dapat mengetahui keberadaan dan peran yang dimainkan Islam, diperlukan pemahaman mendalam terhadap stratifikasi sosial budaya bangsa Arab menjelang dan ketika Alquran diturunkan. Misi Alquran hanya dapat dipahami secara utuh setelah memahami kondisi sosial budaya bangsa Arab. Bahkan bolehjadi, 
sejumlah ayat dalam Alquran (termasuk ayat-ayat yang menjelaskan gender), dapat disalah-pahami tanpa memahami latar belakang sosial budaya masyarakat Arab. Justru itu sebelum membahas lebih jauh, perlu diperkenalkan secara umum kondisi geografis dan pola kehidupan mereka, yang tentunya ikut mengambil peran dalam proses pembentukan budaya masyarakat Arab. Jazirah Arab mempunyai daerah yang cukup luas, dan sebagian besar wilayahnya terdiri dari padang pasir. Hanya sebagian kecil wilayahnya di bagian selatan dan utara, daerah yang subur. Posisi geografisnya yang jauh dari pusat-pusat kerajaan besar dan kondisi alamnya yang sulit dijangkau, menyebabkan kawasan ini luput dari cengkeraman 2 (dua) imperium besar Romawi dan Persia.

Mata pencaharian penduduk kebanyakan beternak bagi mereka yang mendiami kawasan tandus, bercocok tanambagimerekayang berada dikawasan yang subur. Kelangsungan hidup mereka tergantung pada alam, dan pembagian peran dalam masyarakatsangattergantung pada kondisi obyektif keadaan alam. Lakilaki bekerja sebagai pencarinafkahkeluarga dan mempertahankan keutuhan dan kehormatan kabilah (sektor publik), dan perempuan bekerja mengasuh anak dan mengatur urusan rumah tangga (sektor domestik).

Dilihat dari sudut sistem kekerabatan, maka keluarga Arab dapat dibedakan ke dalam 5 (lima) bentuk, yaitu:

1. Tribe (Kabilah/qabilah);

2. Sub Tribe (Sub Kabilah/'asirah);

3. Clan, Lineage (Suku/hamulah);

4. Extended family (Keluarga Besar/ 'àilah);

5. Nuclear family (Keluarga Kecil/ usrah) $)^{6}$

Kelima bentuk keluarga ini ditemukan di daerah tertentu, sekalipun pada daerah yang lain kelima bentuk tersebut tidak dianut secara identik, sesuai dengan watak dasar bangsa Arab yang nomaden; mereka menyesuaikan hidup dengan kondisi obyektif di mana mereka berada.

Pada masa Jahiliyah, anak-anak perempuan kehadirannya tidak diterima sepenuh hati oleh masyarakat Arab. Pandangan mereka ini telah direkam oleh Alquran, mulai dari sikap yang paling ringan yaitu bermuka masam, sampai pada sikap yang paling parah yaitu membunuh bayi-bayi mereka yang perempuan. Informasi ini dapat dibaca dalam QS. an-Nahl (16): 58, sebagai berikut:
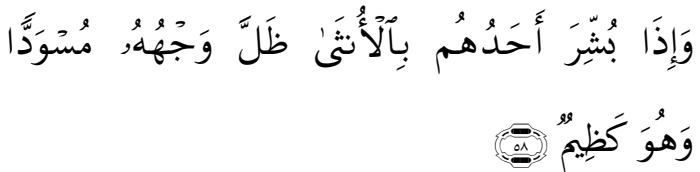

Artinya: dan apabila seseorang dari mereka diberi kabar dengan (kelahiran) anak perempuan, hitamlah (merah padamlah) mukanya, dan Dia sangat marah. 
dan QS.at-Takwir (81): 9

$$
\text { بَأَىيْ ذَنْبِ قُتِلَتْ }
$$

Artinya: karena dosa Apakah Dia dibunuh,

Demikian secara ringkas kondisi geografis serta pola kehidupan bangsa Arab sebelum turunnya agama Islam, selanjutnya akan ditelaah ayat-ayat Alquran dan pemahamannya, terutama yang menyangkut masalah gender.

Bahwa agama Islam yang dibawa oleh Nabi Muhammad SAW., telah memperjuangkan dan berhasil meningkatkan derajat perempuan yang sebelumnya mereka tertindas. Kaum perempuan yang sebelumnya tidak menerima warisan, malah termasuk barang yang diwariskan, oleh Islam diberikan porsi waris yang tetap (faraidh). Islam mendudukkan perempuan sebagai makhluk Allah sederajat dengan pria dengan hak dan tanggungjawabnya yang adil dan seimbang. Tetapi, kenyataan bahwa perempuan Muslimah pada masa-masa berikutnya pernah dan sebagian masih mengalami perlakuan yang berbeda dan diskriminatif, juga telah menjadi catatan historis dan kajian para ahli.

Alquran, sebagai sumber utama dalam ajaran Islam, telah menegaskan ketika Allah Yang Maha Pencipta menciptakan manusia termasuk di dalamnya, laki-laki dan perempuan. Paling tidak ada empat kata yang sering digunakan Alquran untuk menunjuk manusia, yaitu basyar, insan dan al-nas, serta bani adam. ${ }^{7}$ Masing-masing kata ini merujuk makhluk ciptaan Allah yang terbaik (fi ahsan taqwim), meskipun memiliki potensi untuk jatuh ke titik yang serendah-rendahnya (asfala safilin), namun dalam penekanan yang berbeda. Keempat kata ini mencakup laki-laki dan perempuan.

Mengenai asal kejadian manusia ini, Alquran menyatakan dalam surah An-Nisa'(4): 1, sebagai berikut:

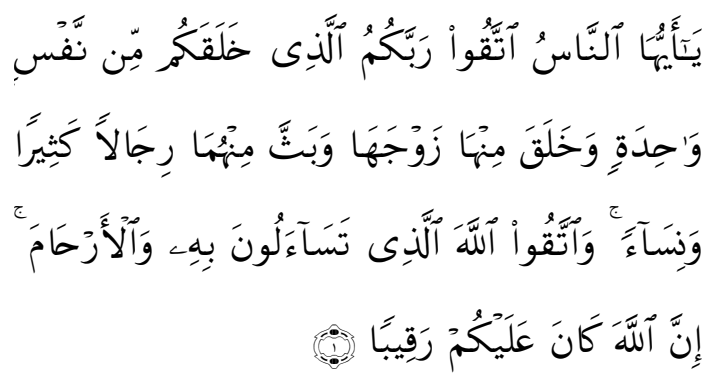

Artinya: Hai sekalian manusia, bertakwalah kepada Tuhan-mu yang telah menciptakan kamu dari seorang diri, dan dari padanya[263] Allah menciptakan isterinya; dan dari pada keduanya Allah memperkembang biakkan laki-laki dan perempuan yang banyak. dan bertakwalah kepada Allah yang dengan (mempergunakan) namaNya kamu saling meminta satu sama lain[264], dan (peliharalah) hubungan silaturrahim. Sesungguhnya Allah selalu menjaga dan mengawasi kamu.

[263] Maksud dari padanya menurut jumhur mufassirin ialah dari bagian tubuh (tulang rusuk) Adam a.s. 
berdasarkan hadis riwayat Bukhari dan Muslim. di samping itu ada pula yang menafsirkan dari padanya ialah dari unsur yang serupa Yakni tanah yang dari padanya Adam a.s. diciptakan. [264] Menurut kebiasaan orang Arab, apabila mereka menanyakan sesuatu atau memintanya kepada orang lain mereka mengucapkan nama Allah seperti :As aluka billah artinya saya bertanya atau meminta kepadamu dengan nama Allah.

Ayat tersebut merupakan penegasan bahwa tidak ada perbedaan antara zat yang dipakai untuk menciptakan perempuan dan yang dipakai untuk menciptakan laki-laki, karena semuanya berasal dari jenis yang sama. Mayoritas ulama tafsir memahami kata "nafs" dalam arti Adam AS. Misalnya al-Jalalayn, al-Qurthubi, al-Biqa'i dan lain-lain, bahkan al-Thabari mengemukakan dalam tafsirnya bahwa seluruh ulama tafsir sepakat mengartikan kata tersebut dengan Adam AS. Dan ada juga yang memahaminya dalam artijenis manusia lelaki dan wanita. ${ }^{8}$

Syekh Muhammad Abduh, alQasimi, dan beberapa ulama kontemporer lainnya memahami demikian, sehingga ayat ini sejalan dengan firman Allah SWT dalam QS. Al-Hujurat: 13.

Memahami "nafs" sebagai Adam AS. Menjadikan zaujaha, yang secara harfiah bermakna pasangannya, adalah isteri Adam AS. yang populer bernama Hawa. Agaknya, karena ayat itu menyatakan bahwa istri Adam AS. diciptakan dari Adam sendiri. Pandangan ini kemudian melahirkan pandangan negatif terhadap perempuan dengan menyatakan bahwa perempuan adalah bagian dari laki-laki. Banyak penafsir menyatakan bahwa pasangan Adam itu diciptakan dari tulang rusuk Adam sebelah kiri yang bengkok.

Agaknya ide kelahiran Hawa dari tulang rusuk Adam AS. tidak sepenuhnya benar, senada dengan yang ditegaskan oleh Muhammad Rasyid Ridha dalam tafsir al-Mannar bahwa adanya pendapat menyatakan perempuan diciptakan dari tulang rusuk Adam AS. adalah terpengaruh dengan kitab perjanjian lama atau dikenal juga dengan khabar Israiliyat. Thabatha'i menguatkan dalam tafsirnya bahwa perempuan (istri Adam) diciptakan dari jenis yang sama dengan Adam, dan ayat tersebut sedikitpun tidak mendukung paham yang beranggapan bahwa perempuan diciptakan dari tulang rusuk Adam. Memang tidak ada petunjuk dari alQur'an yang mengarah ke sana, atau bahkan mengarah kepada penciptaan pasangan Adam dari unsur lain.

Berbicara mengenai prinsipprinsip kesadaran gender dalam perspektif Islam, setidaknya kita dapat 
mengajukan 5 (lima) variabel yang dapat digunakan sebagai ukuran untuk menguji bagaimana kitab suci Alquran memberitakan. Kelima variabel tersebut masing-masing: laki-laki dan perempuan sama-sama sebagai hamba Allah, sebagai khalifah di muka bumi, sebagai yang menerima perjanjian atau sama-sama berikrar akan keberadaan Allah, sebagai hamba yang punya tanggung-jawab, dan sebagai yang berpotensi meraih prestasi. ${ }^{9}$

1. Sebagai hamba Allah. Alquran menyebutkan bahwa salah satu tujuan penciptaan manusia adalah untuk menyembah kepadaTuhan. Penjelasan ini dapat dibaca dalam QS. Az-Zariyat (51): 56, sebagai berikut:

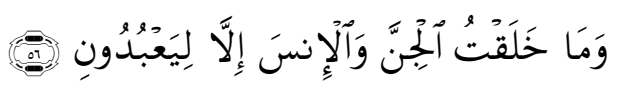

Artinya: dan aku tidak menciptakan jin dan manusia melainkan supaya mereka mengabdi kepada-Ku.

Dalam kapasitas manusia sebagai hamba, tidak ada perbedaan antara laki-laki dan perempuan. Keduanya mempunyai potensi dan peluang yang sama untuk menjadi hamba ideal. Hamba ideal dalam Alquran biasa diistilahkan dengan orang-orang yang bertaqwa (muttaqun), dan untuk mencapai derajat muttaqun ini tidak dikenal adanya perbedaan jenis kelamin, suku bangsa atau kelompok etnis tertentu yang disebutkan dalam QS Al-Hujurat (49): 13, sebagai berikut:

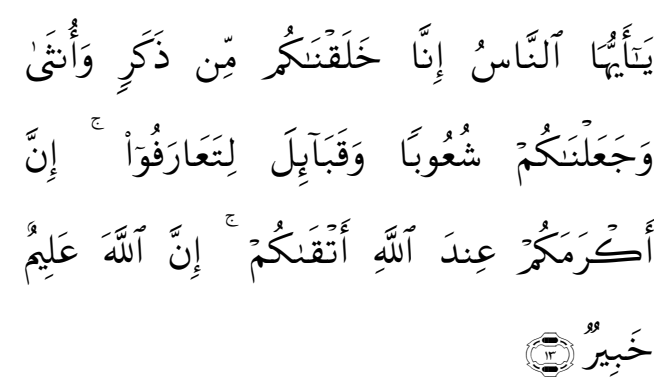

Artinya: Haimanusia, Sesungguhnya Kami menciptakan kamu dari seorang laki-laki dan seorang perempuan dan menjadikan kamu berbangsa bangsa dan bersuku-suku supaya kamu saling kenal-mengenal. Sesungguhnya orang yang paling mulia diantara kamu disisi Allah ialah orang yang paling taqwa diantara kamu. Sesungguhnya Allah Maha mengetahui lagi Maha Mengenal.

Dalam kapasitas sebagai hamba, laki-laki dan perempuan masing-masing akan mendapatkan penghargaan dari Tuhan sesuai dengan kadar pengabdiannya, sebagaimana disebutkan dalam QS. An-Nahl (16): 97, sebagai berikut:

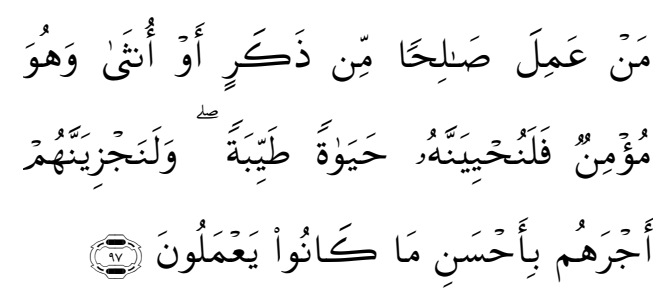


Artinya: Barangsiapa yang mengerjakan amal saleh, baik laki-laki maupun perempuan dalam Keadaan beriman, Maka Sesungguhnya akan Kami berikan kepadanya kehidupan yang baik

2. Sebagai khalifah di bumi. Maksud dan tujuan penciptaan manusia di muka bumi ini adalah, di samping untuk menjadi hamba ('abid) yang tunduk dan patuh serta mengabdi kepada Allah SWT., juga untuk menjadi khalifah di bumi (khalifah fi al-ard). Kapasitas manusia sebagai khalifah di bumi ditegaskan dalam QS. Al-An'am (6): 165, sebagai berikut:

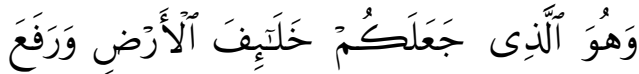

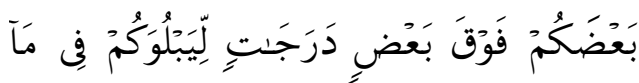

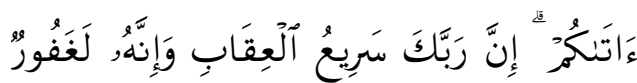

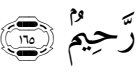

Artinya: dan Dialah yang menjadikan kamu penguasa-penguasa di bumi dan Dia meninggikan sebahagian kamu atas sebahagian (yang lain) beberapa derajat, untuk mengujimu tentang apa yang diberikan-Nya kepadamu. Sesungguhnya Tuhanmu Amatcepat siksaan-Nya dan Sesungguhnya Dia Maha Pengampun lagi Maha Penyayang.

Pada ayat lain disebutkan dalam QS. al-Baqarah (2):30, sebagai berikut:

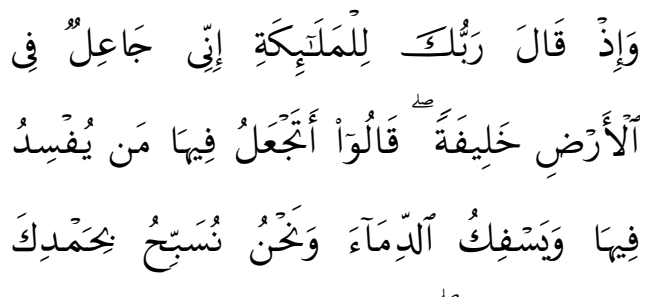

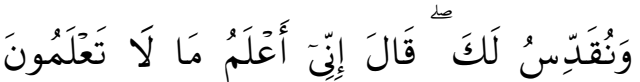

Artinya: ingatlah ketika Tuhanmu berfirman kepada Para Malaikat: "Sesungguhnya aku hendak menjadikan seorang khalifah di muka bumi." mereka berkata: "Mengapa Engkau hendak menjadikan (khalifah) di bumi itu orang yang akan membuat kerusakan padanya dan menumpahkan darah, Padahal Kami Senantiasa bertasbih dengan memuji Engkau dan mensucikan Engkau?" Tuhan berfirman: "Sesungguhnya aku mengetahui apa yang tidak kamu ketahui."

Kata khalifah dalam kedua ayat di atas tidak menunjuk kepada salah satu jenis kelamin atau kelompok etnis tertentu. Laki-laki dan perempuan mempunyai fungsi yang sama sebagai khalifah, yang akan mempertanggungjawabkan tugas-tugas kekhalifahannya di bumi, sebagaimana halnya mereka harus bertanggung-jawab sebagai hamba Tuhan. 
3. Sebagai penerima perjanjian/ikrar ketuhanan yg sama. Laki-laki dan perempuan sama-sama mengemban amanah dan menerima perjanjian primordial dengan Tuhan. Seperti diketahui, menjelang seorang anak manusia keluar dari rahim ibunya, ia terlebih dahulu harus menerima perjanjian dengan Tuhannya (QS.AlA'raf (7): 172).

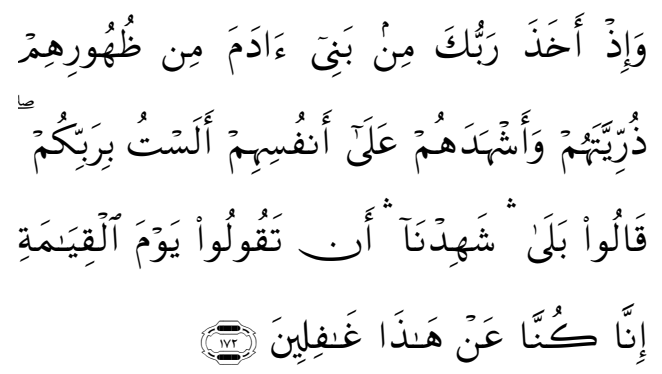

Artinya: dan (ingatlah), ketika Tuhanmu mengeluarkan keturunan anak-anak Adam dari sulbi mereka dan Allah mengambil kesaksian terhadap jiwa mereka (seraya berfirman): "Bukankah aku ini Tuhanmu?" mereka menjawab: "Betul (Engkau Tuban kami), Kami menjadi saksi". (kami lakukan yang demikianitu)agar di hari kiamatkamu tidak mengatakan: "Sesungguhnya Kami (Bani Adam) adalah orangorang yang lengah terhadap ini (keesaan Tuhan)",

Menurut penjelasan Fakhr arRazi, tidak seorang pun anak manusia yang lahir ke muka bumi ini yang tidak berikrar akan keberadaan Tuhan, dan ikrar mereka disaksikan oleh para Malaikat. Tidak ada seorang pun yang mengatakan tidak. Di dalam ajaran Islam, tanggung jawab individual dan kemandirian seseorang telah berlangsung sejak dini, yaitu semenjak dalam kandungan. Sejak awal sejarah kejadian manusia dalam Islam tidak dikenal adanya diskriminasi jenis kelamin. Laki-laki dan perempuan sama-sama menyatakan ikrar ketuhanan yang sama. Dan tambahnya lagi Alquran mengungkapkan bahwa Allah SWT yang Maha Kuasa memuliakan seluruh anak cucu Adam, sebagaimana yang disebutkan dalam firman-Nya QS. Al-Isra' (17): 70, sebagai berikut:

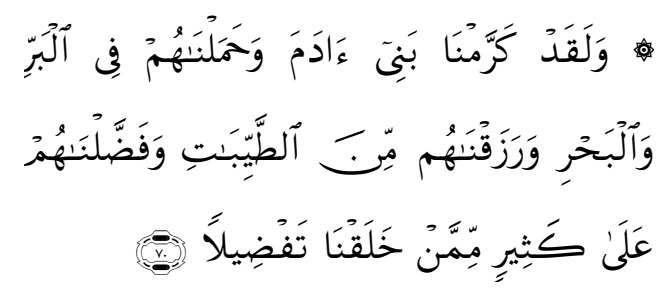

Artinya: dan Sesungguhnya telah Kami muliakan anak-anak Adam, Kami angkut mereka di daratan dan di lautan[862], Kami beri mereka rezki dari yang baik-baik dan Kami lebihkan mereka dengan kelebihan yang sempurna atas kebanyakan makhluk yang telah Kami ciptakan.

\section{Sebagai hamba yang punya} tanggung jawab. Semua ayat yang memuat cerita tentang keadaan Adam dan pasangannya di surga 
sampai keluar ke bumi, selalu menekankan kedua belah pihak secara aktif dengan menggunakan kata ganti untuk dua orang هما (huma), yakni kata ganti untuk Adam dan Hawa, seperti dapat dilihat dalam beberapa kasus berikut: bahwa Adam dan Hawa diciptakan di surga dan memanfaatkan fasilitas surga, disebutkan dalam QS. AlBaqarah (2): 35, sebagai berikut:

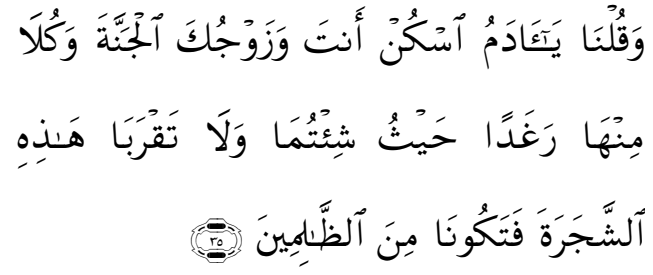

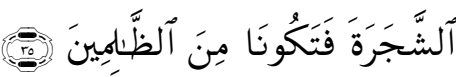

Artinya: dan Kami berfirman: "Hai Adam, diamilah oleh kamu dan isterimu surga ini, dan makanlah makanan-makanannya yang banyak lagi baik dimana saja yang kamu sukai, dan janganlah kamu dekati pohon ini[37], yang menyebabkan kamu Termasuk orang-orang yang zalim.

Adam dan istrinya samasama mendapat godaan dari setan, yang ditegaskan dalam Alquran, QS. Al-A'raf (7): 20, sebagai berikut:

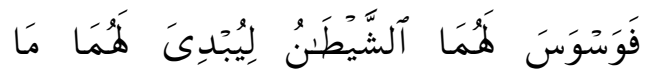

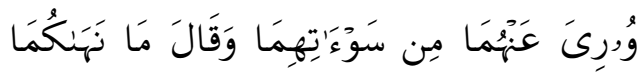

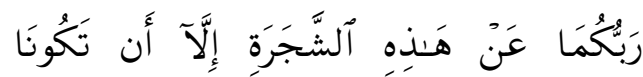

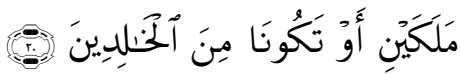

Artinya: Maka syaitan membisikkan pikiran jahat kepada keduanya untuk Menampakkan kepada keduanya apa yang tertutup dari mereka Yaitu auratnya dan syaitan berkata: "Tuhan kamu tidak melarangmu dan mendekati pohon ini, melainkan supaya kamu berdua tidak menjadi Malaikat atau tidak menjadi orangorang yang kekal (dalam surga)".

Keduanya (Adam dan istrinya) sama-sama memakan buah khuldi dan mereka menerima akibat jatuh ke bumi, seperti tertulis dalam QS. Al-A'raf (7):22, sebagai berikut:

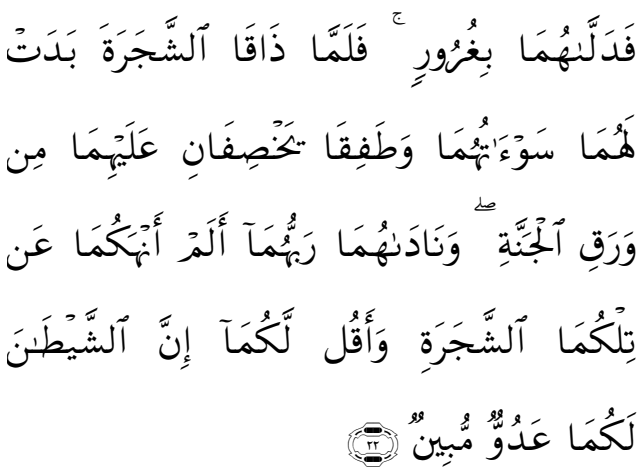

Artinya: Maka syaitan membujuk keduanya (untuk memakan buah itu) dengan tipu daya. tatkala keduanya telah merasai buah kayu itu, nampaklah bagi keduanya auratauratnya, dan mulailah keduanya menutupinya dengan daun-daun surga. kemudian Tuhan mereka menyeru mereka: "Bukankah aku telah melarang kamu berdua dari pohon kayu itu dan aku katakan kepadamu: "Sesungguhnya syaitan 
itu adalah musuh yang nyata bagi kamu berdua?"

Kemudian keduanya samasama memohon ampun dan samasama diampuni Tuhan, yang kisahnya diabadikan dalam QS. AlA'raf (7): 23, sebagai berikut:

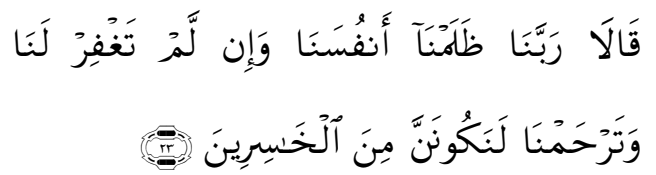

Artinya: keduanya berkata: "Ya Tuhan Kami, Kami telah Menganiaya diri Kami sendiri, dan jika Engkau tidak mengampuni Kami dan memberi rahmat kepada Kami, niscaya pastilah Kami Termasuk orang-orang yang merugi.

Pernyataan-pernyataan dalam Alquran di atas, agak berbeda dengan pernyataan-pernyataan dalam Alkitab yang membebankan kesalahan lebih berat kepada Hawa. Dalam ayat-ayat tersebut di atas, Adam dan Hawa disebutkan secara bersama-sama sebagai pelaku dan bertanggung jawab terhadap perbuatannya tersebut.

\section{Sebagai hamba yang berpotensi} meraih prestasi. Peluang untuk meraih prestasi maksimum tidak ada perbedaan antara laki-laki dan perempuan, sebagaimana ditegaskan secara khusus di dalam firman-Nya surah Ali Imran (3): 195, sbb:

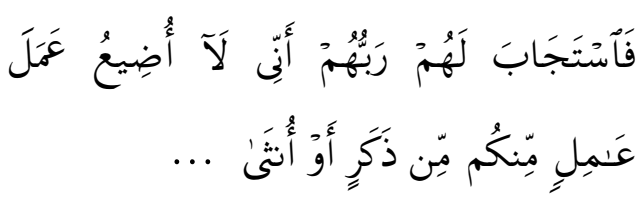

Artinya: Maka Tuhan mereka memperkenankan permohonannya (dengan berfirman): "Sesungguhnya aku tidak menyia-nyiakan amal orang-orang yang beramal di antara kamu, baik laki-laki atau perempuan...

Dalam QS. an-Nisa' (4): 124, Allah menegaskan:
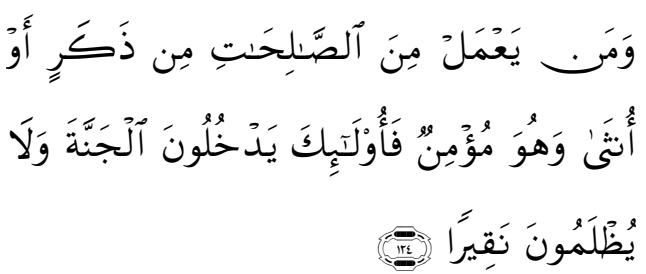

Artinya: Barangsiapa yang mengerjakan amal-amal saleh, baik laki-laki maupun wanita sedang ia orang yang beriman, Maka mereka itu masuk ke dalam surga dan mereka tidak dianiaya walau sedikitpun.

Dan masih banyak lagi ayatayat yang senada, seperti QS. anNahl (16): 97; dan QS. al-Gafir (40): 40.

Ayat-ayat tersebut di atas mengisyaratkan konsep kesadaran gender yang ideal dan memberikan ketegasan bahwa prestasi individual, baik dalam bidang spiritual maupun 
urusan karir professional, tidak mesti dimonopoli oleh salah satu jenis kelamin saja. Laki-laki dan perempuan memperoleh kesempatan yang sama meraih prestasi optimal.

Salah satu obsesi Alquran ialah terwujudnya keadilan di dalam masyarakat. Keadilan dalam Alquran mencakup segala segi kehidupan umat manusia, baik sebagai individu maupun sebagai anggota masyarakat. Karena itu Alquran tidak mentolerir segala bentuk penindasan, baik berdasarkan kelompok etnis, warna kulit, suku bangsa, dan kepercayaan, maupun yang berdasarkan jenis kelamin. Jika terdapat suatu hasil pemahaman atau penafsiran yang bersifat menindas atau menyalahi nilainilai luhur kemanusiaan, maka hasil pemahaman dan penafsiran tersebut terbuka untuk diperdebatkan.

Kelima variabel beserta ayat-ayat yang dikemukakan di atas memberikan informasi bahwa penciptaan manusia sejak awal tidak menunjukkan adanya perbedaan substansi antara laki-laki dan perempuan. Kalaupun antara keduanya mempunyai perbedaan maka substansi perbedaannya tidak pernah ditonjolkan. Ini mengisyaratkan bahwa Alquran mempunyai pandangan yang cukup positif terhadap perempuan.

Dengan demikian, Alquran sebenarnya hanya mengungkapkan persamaan-persamaan antara laki-laki dan perempuan, akan tetapi kitab
Sejarah Islam klasik, terpengaruh dengan pemberitaan kitab Kejadian. Padahal sesungguhnya semangat ajaran yang dibawa oleh Rasulullah SAW. tidak sejalan dengan cerita-cerita yang memojokkan perempuan.

Keberhasilan Nabi Muhammad SAW. membangun pilar-pilar dasar peradaban Islam didasarkan atas kekokohan pribadi Muslim dan solidnya lembaga keluarga yang dibangun dalam prinsip kemitraan cinta-kasih $(\text { jawz })^{10}$ dan resiprositas luhur (mu'asyarah bi al-ma'ruf) untuk membangun keluarga yang sakinah, mawaddah dan rahmah. Nabi MuhammadSAW. mengangkat derajat perempuan dengan memperkuat landasan teologis-spiritual, dan merombak iklim kultural yang berkembang serta menjabarkannya dalam kehidupan keluarganya serta dalam kebijakan pemerintahannya. Koherensi dan konsistensi ajaran Islam dengan praktek Rasulullah inilah yang dicatat sebagai suatu revolusi kultural pada saat itu.

Jika demikian halnya mengapa ada dalam Alquran ayat-ayat yang membedakan perlakuan terhadap perempuan? Untuk mengawali, patut diingat bahwa 'membedakan' perlakuan bukan berarti memperlakukan seorang secara tidak adil. Keadilan (justice) tidaklah identik dengan persamaan (equality). Dalam kajian filsafat, jauh sebelum Islam, Aristoteles sudah 
mengulas konsep keadilan yang dapat disimpulkan pada prinsip 'treating equals equally' (memperlakukan mereka yang sama secara sama). Sama dan beda dari segi apa? Apakah yang mempersamakan dan memperbedakan satu orang dari yang lain?

Memperlakukan mereka yang sama secara berbeda tentu ketidakadilan. Namun jika mereka memang tidak sama, malah jika diperlakukan sama (treating unequals equally), maka ketidak-adilan yang terjadi. Atau, mereka yang sama diperlakukan berbeda (treating equals unequally), tentu kezaliman yang muncul. Yang menjadi pertanyaan sekarang: apakah laki-laki dan perempuan 'sama', hingga harus diperlakukan 'sama', atau mereka berbeda hingga mesti diperlakukan berbeda, atau laki-laki dan perempuan memiliki banyak persamaan, tetapi juga berbagai perbedaan. Kalau begitu mereka harus diperlakukan secara sama dalam aspek-aspek yang mereka sama, serta mesti diperlakukan berbeda dalam aspek-aspek yang memang mereka berbeda.

Perbedaan yang cukup gamblang adalahmasalah perbedaan perlakuan laki-laki dan perempuan terkait dengan nilai kesaksian (dan porsi kewarisan QS. anNisa'(4): 11 dan 176). Masalah lain yang juga tidak sejalan dengan prinsip kesetaraan adalah kedudukan suami isteri dalam rumah tangga, tentang apa yang dimaksud dengan 'kepala keluarga', umumnya didasarkan pada QS. An-Nisa' (4): 34, sebagai berikut:

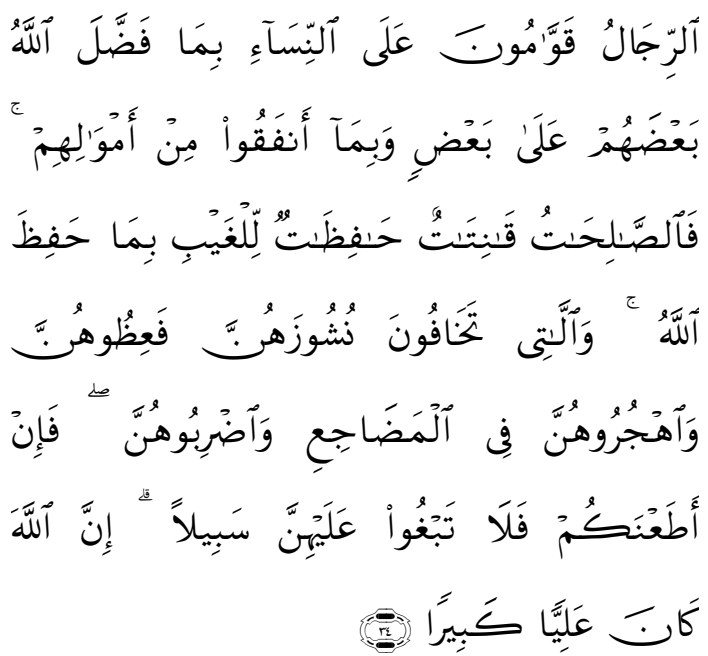

Artinya: kaum laki-laki itu adalah pemimpin bagi kaum wanita, oleh karena Allah telah melebihkan sebahagian mereka (laki-laki) atas sebahagian yang lain (wanita), dan karena mereka (lakilaki) telah menafkahkan sebagian dari harta mereka. sebab itu Maka wanita yang saleh, ialah yang taat kepada Allah lagi memelihara diri.

Tanpa harus masuk dalam kompleksitas penafsiran dan reinterpretasi terhadap ayat-ayat di atas dan yang sejenisnya, ada dua hal pokok yang patut dicermati. Pertama, Alquran sebagai wahyu Allah merupakanhal yang sakral dan absolut, namun pemahaman, interpretasi dan penjabarannya merupakan hasil jerih payah para ulama. Yangkedua, ajaran Islam, karena bersumber dari Allah Yang Maha Tahu dan Bijak, tentu seyogianya merupakan suatu kesatuan yang komprehensif dan tidak kontradiktif antara satu dengan lain. 
Secara prinsipil dan normatif, Islam menghargai dan memperdayakan kaum perempuan. Namun persoalan penindasan dan diskriminasi terhadap perempuan bukalah persoalan laki-laki, melainkan persoalan sistem dan struktur ketidakadilan masyarakat dan ketidakadilan gender, dan salah satunya justru dilegitimasi oleh pemahaman agama yang bias gender. Sehingga menimbulkan ketidakadilan gender dan diskriminasi terhadap perempuan.

Guna mengatasi ketidakadilan gender dapat dilakukan secara kontinu reintepretasi ayat-ayat Al-Qur'an dan hadits yang bias gender, sehingga dapat menerapkan ajaran Islam yang rahmat li al-'alamin sepanjang zaman. Persoalan gender bukanlah persoalan perempuan melawan laki-laki, melainkan gerakan menciptakan suatu sistem hubungan laki-laki dan perempuan yang lebih adil.

\section{KESIMPULAN}

Gender adalah pembedaan peran dan tanggung jawab antar perempuan dan laki-laki sebagai hasil konstruksi sosial budaya masyarakat, yang dapat berubah sesuai dengan tuntutan perubahan zaman. Sedangkan seks (jenis kelamin: laki-laki dan perempuan) tidak berubah dan merupakan kodrat Tuhan. Dalam ajaran agama Islam tidak ada perbedaan antara perempuan dan laki-laki, baik sebagai hamba Allah, sebagai khalifah di bumi, sebagai hamba yang mempunyai tanggung jawab, sebagai hamba yang terlibat dalam drama kosmis, dan sebagai hamba yang berpotensi meraih prestasi. Guna menghindari ketidak-adilan antara perempuan dan laki-laki perlu penafsiran ulang terhadap nash-nash yang bias gender.

Pada akhirnya tidak ada saling merendahkan kejadian yang satu dengan yang lain; tidak ada pernyataan dan perbuatan bahwa yang satu lebih berkuasa dari yang lain; bagimana pun perbedaan pendapat yangada, yangjelas bahwa keduanya saling membutuhkan dan melengkapi, karena tanpa perempuan dunia menjadi gersang, begitujuga tanpa laki-laki dunia menjadi hampa. Allah menjadikan manusia berpasangan supaya ada keseimbangan hidup di dunia.

\section{Endnotes:}

1 Nurdeni Dahri, S. Ag adalah penghulu Pekanbaru Kota, Pekanbaru Provinsi Riau

2 John M. Echols dan Hassan Shadily, Kamus Inggris-Indonesia (Jakarta: Gramedia, cet. XII, 1983), h. 265.

3 Victoria Neufeldt (Ed.), Webster's New World Dictionary (New York: Webster's New World Clevenland, 1984), h. 561.

4 Oakley, Sex, Gender and Society,(New York: Harper and Row, 1972), h. 6, Lihat juga, Linda L. Lindsey, Gender Roles: a Sosiological Perspective, (New Jersey: Prentice Hall,1990), h.2

5 Istilah gender selalu dirancukan dengan istilah jenis kelamin. Dan lebih rancu lagi ketika berbicara persoalan gender yang terbayang adalah jenis kelamin perempuan atau disamakan arti gender dengan persoalan perempuan. Ini adalah pemahaman yang keliru, karena gender bukan menyangkut jenis kelamin perempuan melainkan juga jenis kalamin laki-laki. Jadi sex secara umum digunakan untuk mengidentifikasi perbedaan laki-laki dan perempuan dari segi anatomi biologi. Lebih tegas jenis kelamin (sex) 
Nurdeni Dahri: Kesadaran Gender yang Islami

adalah perbedaan biologis hormonal dan patologis antara perempuan dan laki-laki. Misalnya laki-laki memiliki penis, testis, dan sperma, sedangkan perempuan mempunyai vagina, payudara, ovum dan rahim. H.T. Wilson, Sex and Gender,aking Cultural Sense of Civilization,(New York: Kobenhavn, E.J.Brill,1989),h. 2

6 Hisyam Sharabi, Neopatriachy: a Theory of Distorted Change in Arab Society (New York: Oxford: Oxford University Press, 1984), h. 31

7 Alquran memang menyebut kata Adam sebanyak 25 kali, lihat A.Hamid Hasan Qolay, Kunci Indeks dan Klasifikasi Ayat-ayat Alquran, Jilid I, (Bandung: Pustaka, 1989), h. 51-52. Kata tersebut adalah pinjaman dari bahasa Ibrani, yang dalam kenyataannya merupakan suatu kata benda kolektif, berarti 'manusia' Redaksi riwayat di atas sangat mirip dengan redaksi kitab Kejadian, khususnya pasal 21 dan 23 yang disebutkan sebelumnya. Riwayat-riwayat semacam ini banyak diintrodusir di dalam kitab-kitab Tafsir klasik maupun kitab-kitab Sejarah Islam seperti, Tarikh al-Umam wa al-Muluk, oleh at-Tabari; al-Kamil fi atTarikh, oleh Ibn Asir; as-Sirah an-Nabawiyah, oleh Ibn Hisyam. Kitab-kitab klasik tersebut kelihatannya cenderung kurang selektif memasukkan kisah-kisah israiliyat ke dalam karyakarya mereka. Dan yang sudah pasti sebagai akibat kekurang selektifan mereka, membuat kisah-kisah tersebut juga cenderung memojokkan kaum perempuan. Imam Bukhari dan Muslim juga meriwayatkan hadis yang intinya berbunyi:

$$
\begin{aligned}
& \text { حدثنى موس بن هارون قال: أخبرنا عمرو بن حماد قال: ثنا } \\
& \text { اسبط عن السدى قال: اسكن آدم الجنة فكان يمشى فيها } \\
& \text { وحشا ليس له زوج يسكن اليها فنام نومة فاستيقظ فاذا عند الد الهند }
\end{aligned}
$$

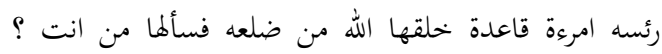

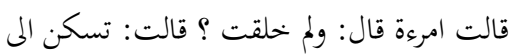

Dari Abi Hurairah RA. berkata: Rasulullah SAW. bersabda: "Sesungguhnyaperempuan seperti tulang rusuk, jika kalian mencoba meluruskannya ia akan patah. Tetapijika kalian membiarkannya maka kalian akan menikmatinya dengan tetap dalam keadaan bengkok" (HR. Bukhari dan Muslim).

8 Tafsir at-Thabari, Jilid I, h. 267. Salah-satu pemberitaan tentang kejadian perempuan tersebut dapat dilihat dalam Tafsir at-Thabari yang menguraikan, sebagai berikut:

$$
\begin{aligned}
& \text { عن ابى هريرة رضى الله عنه قال: قال رسول الله صلى الله عليه }
\end{aligned}
$$

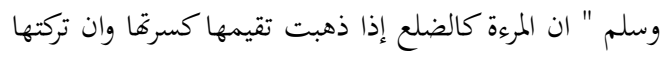

$$
\begin{aligned}
& \text { استمتعت بها وفيها عوج" رواه البخارى ومسلم. }
\end{aligned}
$$

Artinya:

Diriwayatkan dari Musa ibn Harun berkata: saya diberi tahu oleh Amr Ibn Hammad dari Asbat dari as-Sadi berkata: Ketika Tuhan menempatkan Adam di surga ia hidup dan berjalan sendirian tanpa didampingi pasangan. Suatu ketika seorang perempuan yang Allah ciptakan dari tulang rusuknya. Adam bertanya: Siapa anda? Dijawab"Aku seorang perempuan", Adam bertanya: Untuk apa anda diciptakan ? Dijawab: Supaya kamu tinggal bersamaku".

9 Nasaruddin Umar, Argumen Kesetaraan Jender Perspertif al-Quran (Jakarta: Paramadina, 2001), h. 248-265Yanggo, Huzaimah Tahido, 1996, Membincang Feminisme, Surabaya: Risalah Gusti

10 Riffat Hasan memparmasalahkan, mengapa selalu dikatakan Adam wa zawj, sekiranya Adam laki-laki maka kata paling tepat digunakan ialah kata zawjah. (Lihat Riffat Hasan, “Teologi Perempuan dalam Tradisi Islam,"dalam Ulumul Qur'an, Vol.1, 1990/1410 H., h. 51). Akan tetapi alasan ini lemah, karena kata zawj tidak mesti berarti isteri, dan tidak mesti memakai huruf ta marbutah (zawjah) sebagai simbol perempuan (muannats) untuk menunjukkan makna isteri, karena yang ditekankan pada ayat ini ialah pasangan (pair), seperti binatang dan tumbuh-tumbuhan yang berpasang-pasangan (Q., s. Thaha/20:53 dan s. alSyura/42:11). Lagi pula kata ganti (hlamir) yang merujuk ke Adam semuanya menggunakan dhamir mudzakkar, di antaranya paling tegas ialah uskun anta wa zawjuk-a 'l-jannah (Q., s. al-Baqarah/2:35 dan s. al-A'raf/7:19). Kata uskun sudah cukup mengisyaratkan Adam sebagai mudzakkar tetapi diperkuat (ta'kid) dengan kata anta, kata ganti untuk orang pertama tunggal laki-laki.

\section{DAFTAR PUSTAKA}

Abdullah, Irwan, 1997, Sangkan Paran Gender, Yogyakarta: Penerbit Pustaka Pelajar.

Abdullah, Irwan, 2001, Seks, Gender dan Reproduksi Kekuasaan, Yogyakarta: Tarawang Press.

Amasari (Member of PSG LAIN), Laporan Penelitian Pendidikan Berujatuasan Gender,Banjannasin: IAIN Antasari, 2005

Asrohah, Hanun ,Sosiologi Pendidikan, Surabaya: Kopertais Press, 2008, cet. 1 
Arifin, M, 1993, Ilmu Pendidikan Islam, Jakarta: Penerbit Bumi Aksara.

Brannon, Linda, 1999. Gender: Psychological Persective, Boston: Allyn and Bacon.

Daradjat, Zakiyah dkk, 2000, Ilmu Pendidikan Islam, Jakarta: Penerbit Bumi Aksara.

Darwin, Muhajir, Tukiran, 2001, Menggugat budaya patriarkhi, Yogyakarta: Penerbit PPK Universitas Gadjah Mada dan Ford Foundation.

Dzuhayatin, Siti ruhaini, 1996, Membincang Feminisme, Surabaya: Penerbit Risalah Gusti.

Echols, John M, 1996, Kamus Inggris Indonesia, Jakarta: Penerbit Gramedia.

Fakih, Mansour, 1998, Analisisi Gender dan Transformasi Sosial, Yogyakarta: Penerbit Pustaka Pelajar.

Forum Kajian Kitab Kuning (FK3), 2001, Wajah Baru Relasi Suami Istri; Tela'ah Kitab Uqud Al Lujjayn, Yogyakarta: LkiS.

Huda, Hizbullah, 2000, Feodalisme Pendidikan, Majalah Edukasi Edisi 31/Juni.

Ilyas, Hamim, 2002, Rekonstruksi Metodologis Wacana Kesetaraan Gender dalam Islam, Yogyakarta: Penerbit Pustaka Pelajar.

Lips, Hilary M., 2001, Sex and Gender: An Introduction, california: Mayfield Publishing company.
Megawangi, Ratna, 1999, Membiarkan Berbeda, Bandung: Penerbit Mizan.

Mosse, Julia Cleves, , 1996, Gender dan Pembangunan, Yogyakarta: Pustaka Pelajar dan RIFKA ANNISA.

Muhammad, Husein, 2001, Fiqih Perempuan, Yogyakarta: LKiS

Mulkhan, Munir, 2002, Nalar Spiritual Pendidikan, Yogyakarta:Tiara Wacana.

Nelli, Jumni. Kedudukan Perempuan Dalam Hukum Islam: Perspektif Analisis Gender, dalam Jurnal Hukum dan HAM UIN Suska Riau, Vol. 6 No.2. 2009

Sindunata, 2000, Membuka Masa Depan AnakAnak Kita, Yogyakarta: Kanisius.

Syuqqah, Abu, 1996, Jati Diri Wanita Menurut Islam, Bandung: Penerbit Al-Bayan dan Mizan.

Stewart, Lea P., et all, 2003, Communication and Gender, Boston: Allyn and Bacon.

Suhartini, "Dimensi Gender dalam Pemberdayaan Masyarakat di Daerah Rawan Longsor", dalam Model-model

Tafsir, Ahmad, 1994, Ilmu Pendidikan dalam PerspektifIslam, Bandung: Rosdakarya.

Umar Nasaruddin, 2001, Argumen Kesetaraan Gender, Jakarta: Paramadina.

Wolf, Naomi, 1999, Geger Gender, Yogyakarta: Pustaka Semesta Press.

Yanggo, Huzaimah Tahido,1996, Membincang Feminisme, Surabaya: Risalah Gusti 